https://doi.org/10.37208/tgn27214

\section{The crystal jellyfish (Aequorea vitrina) in Loch Bracadale, Isle of Skye, Scotland}

\author{
M. O’Reilly ${ }^{1} \&$ P. Semler ${ }^{2}$ \\ ${ }^{1}$ Scottish Environment Protection Agency, Angus \\ Smith Building, 6 Parklands Avenue, Eurocentral, \\ Holytown, North Lanarkshire ML1 4WQ \\ ${ }^{2} 11$ Ullinish, Struan, Isle of Skye IV56 8FD \\ E-mail: myles.oreilly@sepa.org.uk
}

Jellyfish are among the most conspicuous organisms in Scottish seas during the summer months and include several well known species such as the moon jellyfish (Aurelia aurita), the lion's mane jellyfish (Cyanea capillata), or the barrel jellyfish (Rhizostoma octopus) (Marine Conservation Society, 2019). Most large coastal jellyfish belong to the class Scyphozoa in which the free swimming sexual stage, the medusa, is very large and the overwintering polyp stage, the scyphostoma, is comparatively small and attaches to rocks, stone or shells on the seabed (Hayward \& Ryland, 2017). The morphology and biology of all British Scyphozoa has been investigated in detail by Russell (1970a) and the same author also produced identification guides for all the Scyphozoa of the North Atlantic (Russell, 1976, 1978).

However, there are other jellyfish in British waters, which are from the class Hydrozoa. These are better known as hydroids, or sea firs, forming branching growths of polyps, which attach to rocks, stones, or seaweeds. There are over 100 species of hydroid found in British waters and many of these also produce a swimming medusa (Cornelius, 1995a,b; Schuchert, 2012; Hayward \& Ryland, 2017). The known medusae of British hydroids have also been investigated and beautifully illustrated in a monograph by Russell (1953). Most of the British hydroid medusae are small with around half under $1 \mathrm{~cm}$ in size and the remainder rarely attaining $5 \mathrm{~cm}$. However, there are a few larger species with diameters ranging from six to over $20 \mathrm{~cm}$, i.e. comparable in size to the scyphozoan medusae.

In the summer of 2012, dozens of transparent jellyfish, up to around $15 \mathrm{~cm}$ diameter, were observed by PS at Colbost Point (NG308394) in Loch Bracadale, Isle of Skye, Scotland. The jellyfish were first spotted on 9th July swimming close to the shore (Fig. 1). They were still present in the area ten days later when a smaller individual (diameter around $7 \mathrm{~cm}$ ) was captured and placed in a large beaker for close-up photography (Fig. 2). The jellyfish were mostly transparent with a circlet of whitish radial canals and long marginal tentacles. They were readily identifiable as crystal jellyfish of the genus Aequorea, being distinct from any of the more common scyphozoan jellyfish found inshore (Naylor, 2011).

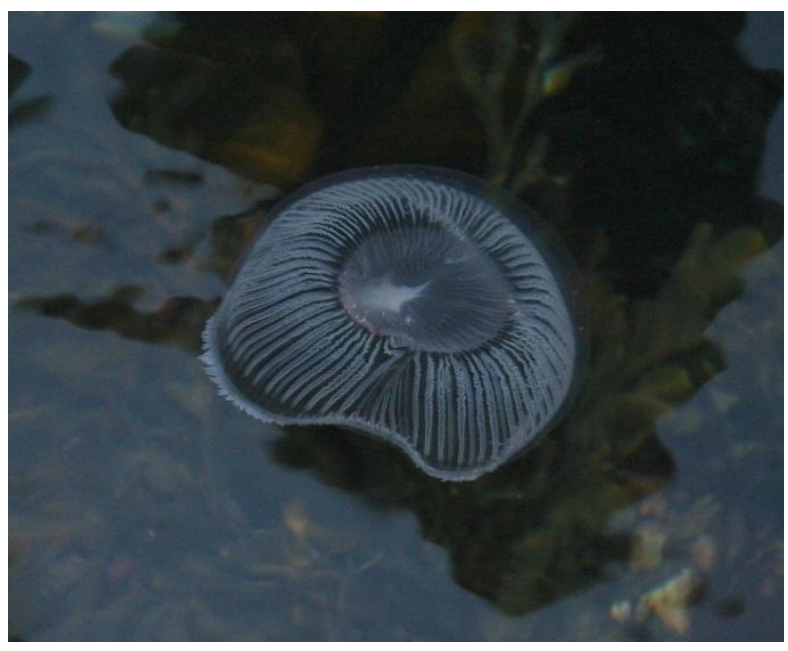

Fig. 1. Crystal jellyfish (Aequorea vitrina), around $15 \mathrm{~cm}$ diameter, swimming by water's edge at Colbost Point, Loch Bracadale, Isle of Skye, Scotland, 9th July 2012. (Photo: P. Semler)

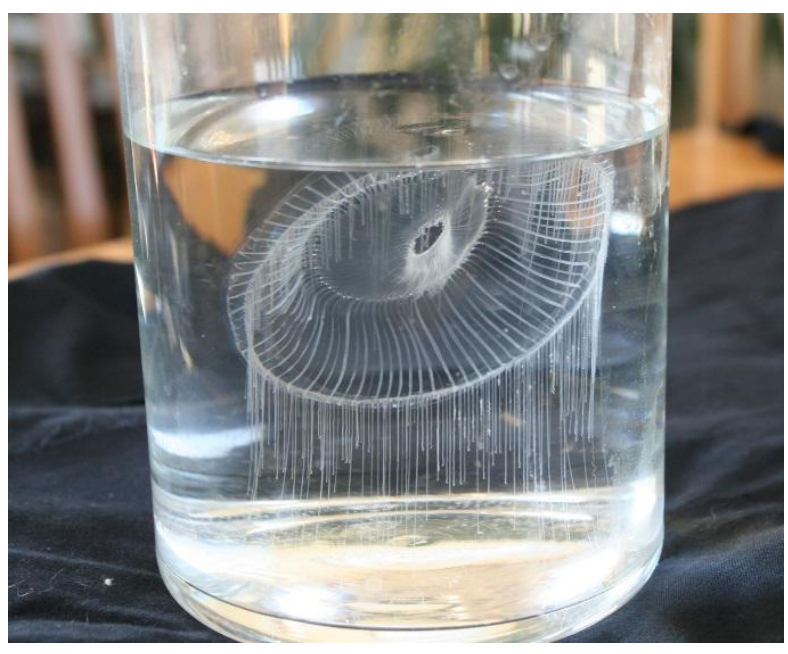

Fig. 2. Captured crystal jellyfish (Aequorea vitrina), diameter about $7 \mathrm{~cm}$, from Colbost Point, Loch Bracadale, Isle of Skye, Scotland, 19th July 2012. (Photo: P. Semler)

Of the four Aequorea species known from British waters, A. macrodactyla and A. pensilis are recorded only from the south-west (drifting from waters further south). The other two, A. vitrina and A. forskalea, are described as common (Cornelius, 1995a), though both are referred to as sparse around mainland Scotland (Fraser, 1972). The captured specimen from Loch Bracadale had around 100 radial canals with approximately three marginal tentacles per radial canal, indicating it to be A. vitrina (Russell, 1953, 1970b; Cornelius, 1995a). The National Biodiversity Network Atlas (NBN, 2019) shows only six records for A. vitrina in Scottish waters, occurring in Orkney, Shetland, the 
island of North Rona and Loch Carron, Wester Ross, Highland. In contrast, there are 27 records for $A$. forskalea, mostly scattered around the north and northwest of Scotland with one find from Loch Eishort, Isle of Skye and a single east coast record from North Queensferry in the Firth of Forth. Hence the occurrence of A. vitrina in Scottish waters seems to be relatively unusual. Observations by PS in the Loch Bracadale area since 2012 have, to date, produced no further sightings.

Only two other hydrozoan medusae from British coastal waters exceed $5 \mathrm{~cm}$ in diameter but are unlikely to be confused with Aequorea species. One of these, Tima bairdii, attains a diameter of $6.5 \mathrm{~cm}$. It has only four radial canals, a distinct protruding mouth, and 16 marginal tentacles. It is frequent in the North Sea and may strand in large numbers on the east coast of Scotland and north-east of England. The other species, the white-cross jellyfish (Staurophora mertensii), is one of the largest hydrozoan medusae known and may reach over $20 \mathrm{~cm}$ in diameter. It may be mature from around $4.5 \mathrm{~cm}$ and has four radial canals (forming the white cross), a non-protruding mouth, and over 100 marginal tentacles. It is a vagrant from the north and has been recorded in Shetland and along the north-east coast of Britain as far south as Northumberland, and also off the west of Scotland in Clyde Sea Area.

The 2012 crystal jellyfish sighting from Skye is highlighted here as most hydrozoan jellyfish are likely to go unrecognised. They are missing from most sea shore guides, although A. forskalea is included in guides by Naylor (2011) and Trewhella \& Hatcher (2016). Crystal jellyfish could be mistaken for juvenile moon jellyfish. Indeed a large swarm of puzzling jellyfish, observed in Liverpool harbour, England by MOR in October 2007, were initially thought to be moon jellyfish. They were transparent but lacked the four violet gonad rings characteristic of moon jellyfish and at around $10-15 \mathrm{~cm}$ diameter were rather small for moon jellyfish so late in the year. Unfortunately it was not possible to get close enough to these jellyfish to see any morphological details but it seems possible that these might have been an unusual occurrence of Aequorea crystal jellyfish.

Jellyfish blooms have become a potential problem for aquaculture and just a few weeks later in November 2007, swarms of the mauve stinger jellyfish (Pelagia noctiluca), an infrequently recorded scyphozoan jellyfish, caused mass mortalities of salmon at a marine cage fish farm at Glenarm Bay in Northern Ireland (BBC News, 2007). Around the same time, an invasion of mauve stingers and a smaller hydrozoan medusa, Solmaris corona, caused the death of numerous caged salmon in Skye (Nickell et al., 2010). It seems then that in November 2007 an exceptional incursion of atypical pelagic jellyfish extended along the west coast of Scotland and into the Irish Sea, perhaps reaching as far as Liverpool.

It is hoped that highlighting some of these unusual jellyfish will encourage beachcombers and naturalists to look out for such interesting visitors to our shores. Rare or unusual species could appear almost anywhere and even species previously unknown in Scottish waters could turn up (see Govindarajan et al., 2019). A similar jellyfish invasion caused the death of thousands of caged salmon in North Uist in the Outer Hebrides during November 2014 (BBC News, 2014).

\section{REFERENCES}

BBC News (2007). Jellyfish attack destroys salmon. http://news.bbc.co.uk/1/hi/northern_ireland/710663 1.stm Accessed 18th November 2019.

BBC News (2014). Jellyfish swarm kills 300,000 salmon at Uist fish farm. https://www.bbc.co.uk/news/uk-scotlandhighlands-islands-30493457 Accessed 18th November 2019.

Cornelius, P.F.S. (1995a). North-West European Thecate Hydroids and their Medusae. Part 1: Introduction, Laodiceidae to Haleciidae. Synopses of the British Fauna (New Series), No. 50. Field Studies Council, Telford.

Cornelius, P.F.S. (1995b). North-West European Thecate Hydroids and their Medusae. Part 2: Sertulariidae to Campanulariidae. Synopses of the British Fauna (New Series), No. 50. Field Studies Council, Telford.

Fraser, J.H. (1972). The distribution of Medusae in the Scottish area. Proceedings of the Royal Society of Edinburgh (B), 74, 1-25. https://doi.org/10.1017/S0080455X00012285

Govindarajan, A.F., Källström, B., Selander, E., Östman, C. \& Dahlgren, T.G. (2019). The highly toxic and cryptogenic clinging jellyfish Gonionemus sp. (Hydrozoa, Limnomedusae) on the Swedish west coast. PeerJ 7, doi:10.7717/peerj.6883. https://doi.org/10.7717/peerj.6883

Hayward, P.J. \& Ryland, J.S. (Editors) (2017). Handbook of the Marine Fauna of North-west Europe. (2nd edition). Oxford University Press, Oxford.

https://doi.org/10.1093/acprof:oso/9780199549443. 001.0001

Marine Conservation Society (2019). Jellyfish survey. https://www.mcsuk.org/downloads/wildlife/Jellyfis hguide.pdf

Naylor, P. (2011). Great British Marine Animals. (3rd edition). Sound Diving Publications, Plymouth.

NBN (2019). National Biodiversity Network. https://nbn.org.uk/ Accessed 18th November 2019.

Nickell, T., Davidson, K., Fox, C., Miller, P., \& Hays, G. (2010). Developing the Capacity to Monitor the Spatial and Temporal Distribution of Jellyfish in Western Scottish Waters. The Crown Estate, London.

Russell, F.S. (1953). The Medusae of the British Isles. Anthomedusae, Leptomedusae, Limnomedusae,Trachymedusae and Narcomedusae. Cambridge University Press, Cambridge. (Available from: https://www.mba.ac.uk/nmblpublications\#b234)

Russell, F.S. (1970a). The Medusae of the British Isles. II. Pelagic Scyphozoa with a Supplement to the First 
Volume on Hydromedusae. Cambridge University Press, Cambridge. (Available from: https://www.mba.ac.uk/nmbl-publications\#b234)

Russell, F.S. (1970b). Hydromedusae. Family Aequoreidae. Fiches d'Identification $d u$ Zooplancton No. 128, ICES, Copenhagen.

Russell, F.S. (1976). Scyphomedusae of the North Atlantic. Order: Coronatae, Families: Atollidae, Nausithoidae, Paraphyllinidae, Periphyllidae. Fiches d'Identification du Zooplancton No. 152. ICES, Copenhagen.

Russell, F.S. (1978). Scyphomedusae of the North Atlantic (2). Families Pelagiidae, Cyaneidae, Ulmaridae, Rhizostomatidae. Fiches d'Identification $d u$ Zooplancton No. 158. ICES, Copenhagen.

Schuchert, P. (2012). Athecate Hydroids and their Medusae. Synopses of the British Fauna (New Series), No. 59. Field Studies Council, Telford.

Trewhella, S. \& Hatcher, J. (2016). The Essential Guide to Beachcombing and the Strandline. Wild Nature Press, Princeton. 